MINERALOGIA, 40, No. 1-4: 31-42 (2009)

DOI: 10.2478/v10002-009-0006-Z

www.Mineralogia.pl

MineRALOGICAL SOCIETY OF POLAND

POLSKIE TOWARZYSTWO MINERALOGICZNE

Original paper

\title{
First Polish textbooks on mineralogy
}

\author{
Wojciech NARĘBSKI ${ }^{1}$
}

I Professor emeritus of geochemistry and petrology, fellow of the Polish Academy of Arts and Sciences,
Address: 30-124 Krakow ul. Żelechowskiego 4/30; e-mail: wnarebski@op.pl

Received: October 27, 2009

Received in revised form: March 2, 2010

Accepted: March 10, 2010

Available online: March 30, 2010

Abstract. First Polish textbooks on mineralogy, published between 1780s-1820s mostly in Vilna, are presented and their contents briefly discussed. Authors of these textbooks, lecturing at the Vilna University, being A. G. Werner's students, played an important role in propagating most recent ideas in mineralogy and related sciences. They were also the authors of pioneer Polish mineralogical nomenclature, which corresponded to the internationally recognised terms.

Key-words: textbooks on mineralogy, history of mineralogy in Poland

The Mineralogical Society of Poland is currently celebrating its $40^{\text {th }}$ anniversary, but the tradition of mineralogical sciences in our country dates back to the second half of $18^{\text {th }}$ century. This is documented, first of all, by pioneer books on the subject which appeared in that period.

It is considered that the first Polish book, devoted to useful minerals, was published in Warsaw in 1781-1782 by the provincial priest Jan Krzysztof Kluk (1739-1796). This monograph, entitled "Rzeczy kopalnych osobliwie zdatniejszych szukanie, poznanie i zażycie" (Exploration, identification and application of useful minerals), presenting objectively the state of geosciences in the first half of $18^{\text {th }}$ century, was recommended by the Commission on National Education as a school book (Fig. 1). This Commission, formed in 1773, significantly modernized the educational system in the Polish-Lithuanian Commonwealth. One of its achievements was concentrating higher education in the capitals of the two united countries: 
Cracow and Vilna. In their reformed universities, departments of natural history were established.

After the complete partition of Poland in 1795 by the three neighbouring powers of Russia, Prussia and Austria, when Poland and Lithuania disappeared from the map of Europe, the conditions for proper modern education were much more difficult due to the russification and germanization politics of the occupants. Consequently, scientific activity was concentrated mainly in already well-known reformed universities of Cracow and Vilna (established in 1364 and 1579 , respectively). This refers also to the natural sciences. It should be emphasized that separate departments of natural history were formed in 1803 in the capital of Lithuania and eight years later (1811) in Cracow. Vivid activity of geoscientists of the Vilna's Alma Mater, named by tsarist order Imperatoria Universitas Vilnensis, was manifested by publishing several text-

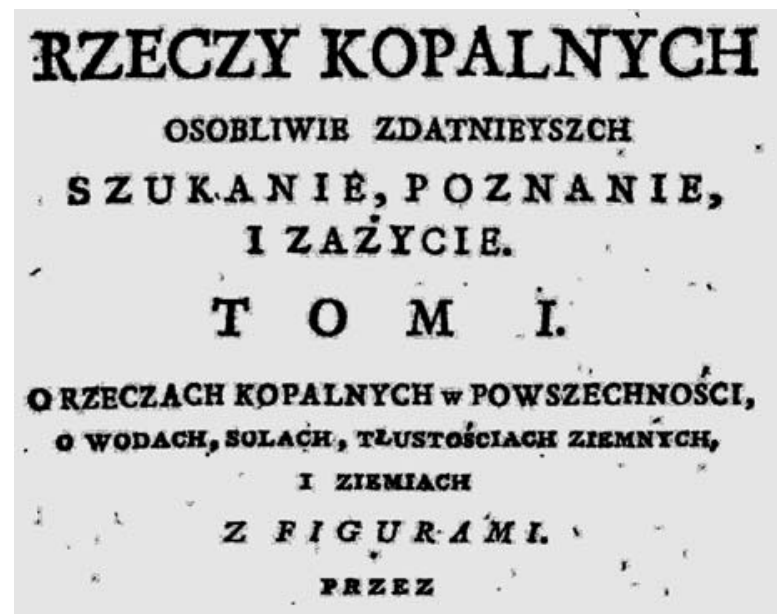

X. KRZYSZTOFA KLUKA

LANOKIKA ERUSWICKIBGO, DZIBTANA DR OHICKLBGO, PROBOSZCZA CIRCHANAWIBCKLREO.

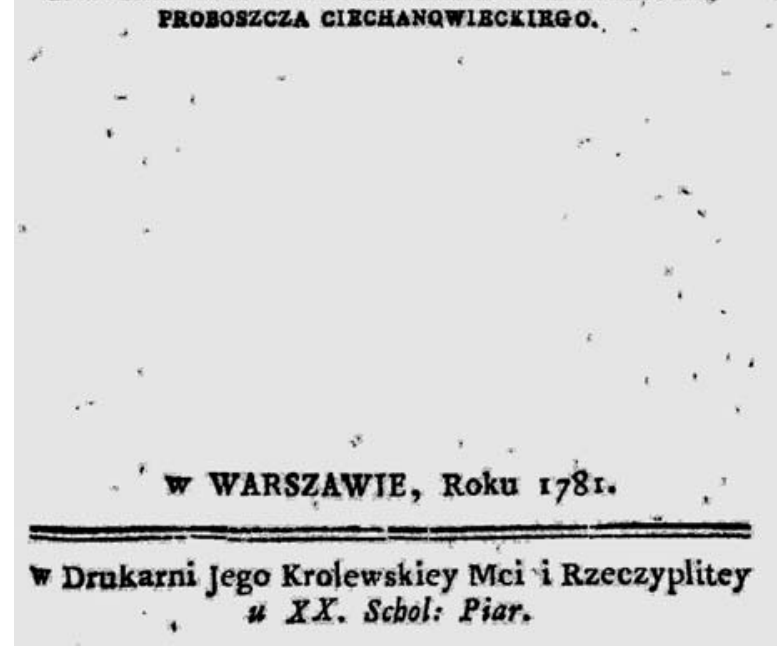

Fig. 1. Title page of "Rzeczy kopalnych osobliwie zdatniejszych szukanie, poznanie i zażycie" (Exploration, identification and application of useful minerals) by Jan Krzysztof Kluk 
books on mineralogy in Polish. As the students of A.G. Werner's (1750-1817) school, they were lecturing and propagating the system of mineralogy of their Freiberg master.

In 1806, the first lecturer of mineralogy in Vilna, Roman Symonowicz (1763-1813), published the first original Polish textbook on mineralogy entitled "O stanie dzisiejszym mineralogii" (On the present state of mineralogy; Fig. 2). It was devoted to a concise presentation of Werner's basic principles of oryctognosy (mineralogy) and geognosy (geology) and to a critical analysis of R. J. Haüy's (1743-1822) system based on the physical and chemical properties of minerals. Nevertheless, it should be stressed that Symonowicz was acquainted with the achievements of such mineral chemists as A.F. Cronstedt (1722-1765), M.H. Klaproth (1743-1817) and Th.O. Bergmann (1735-1784), author of the first chemical classification of minerals; Symonowicz, however, did not fully appreciate their achievements. Importantly, in his

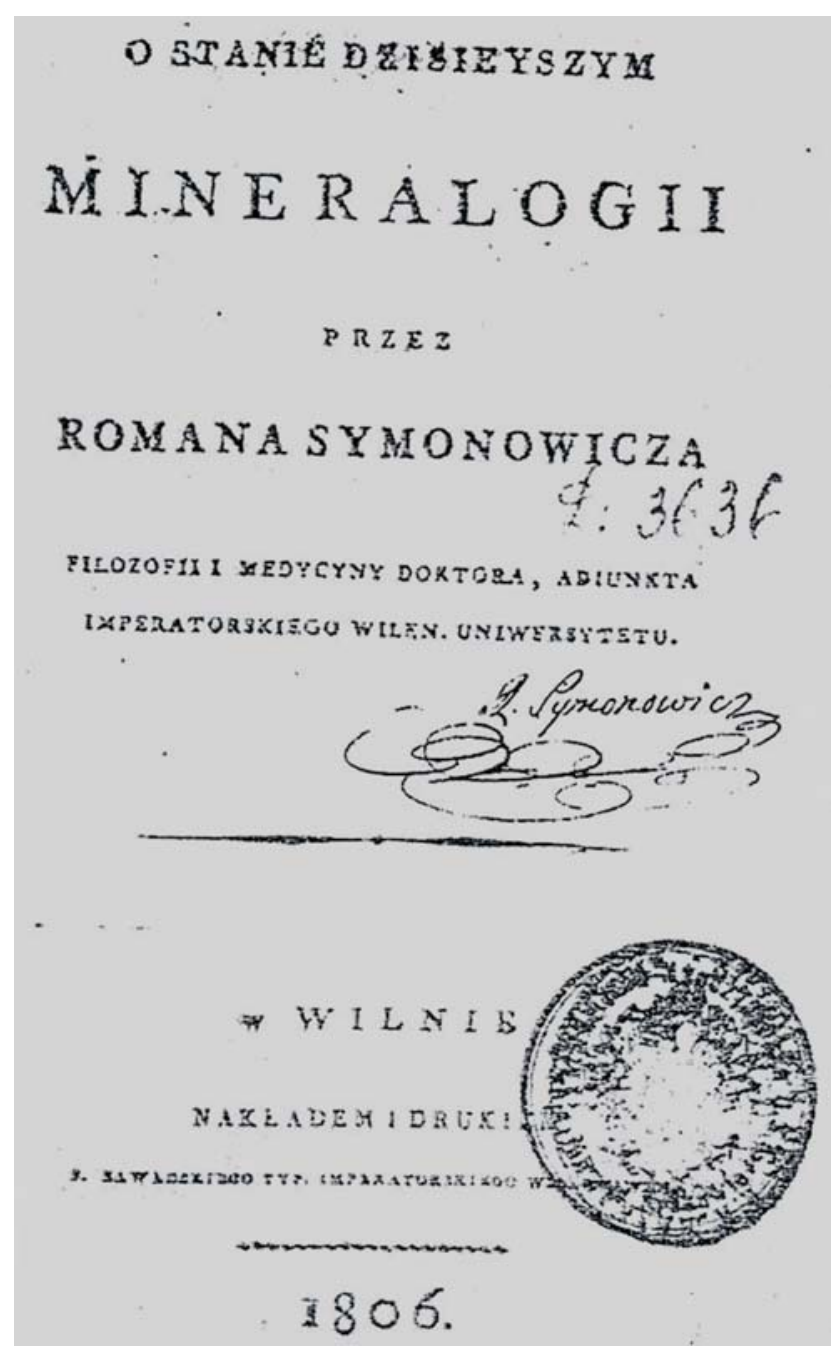

Fig. 2. Title page of "O stanie dzisiejszym mineralogii"

(On the present state of mineralogy) by Roman Symonowicz 
textbook, we find for the first time in the Polish scientific literature such names of minerals as feldspar, mica, hornblende, galena, calcareous and heavy spar, gypsum and others. Some of the names are rather descriptive and therefore long, e.g. white and black silver ore. Symonowicz also introduced such general terms as fracture, cleavage and fissility.

The first exhaustive university textbook (611 pages), entitled "Poczatki mineralogii podtug Wernera ułożone dla stuchaczów akademickich" (Rudiments of mineralogy according to Werner arranged for listeners of academic lectures) was edited in 1816 by another student of the Freiberg master and lecturer of mineralogy at the Vilna university, Feliks Drzewiński (1788-1850) (Fig. 3). Following A.G. Werner's opinion, in a rather short general part of this textbook, the author paid particular attention to the external physical properties of minerals. Among chemical tests, only flame colouration and solubility in acids were discussed.

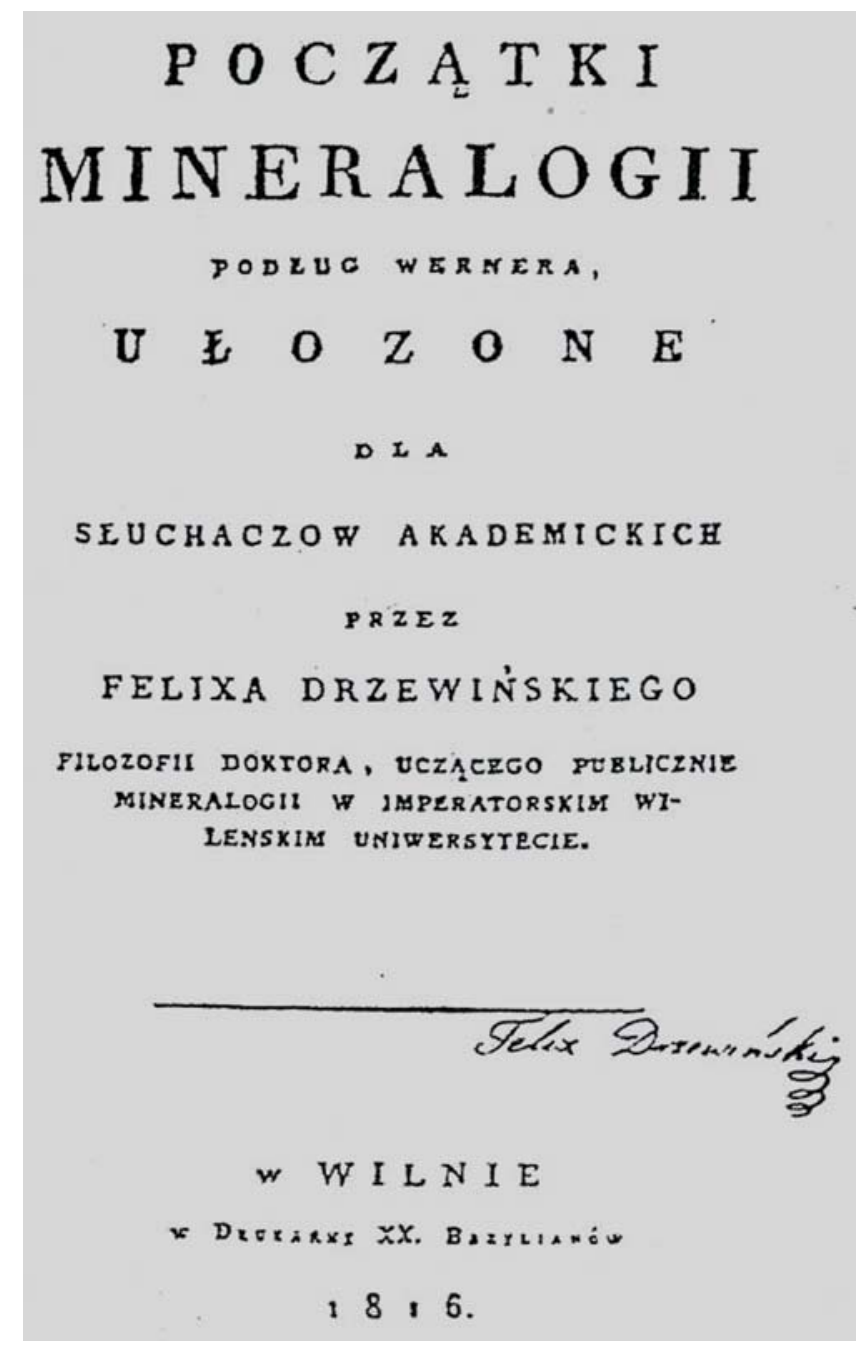

Fig. 3. Title page of "Poczatki mineralogii podlug Wernera ułożone dla sluchaczów akademickich" (Rudiments of mineralogy according to Werner arranged for listeners of academic lectures) by Felix Drzewiński 
In the detailed part of his book, Drzewiński applied the Wernerian systematics of minerals based on Avicenna's principles but taking into account their chemical properties as the criteria for subdivision into genera, species and varieties. He subdivided the mineral kingdom into four classes: earths and stones, salts, combustible substances and metals.

Altogether 292 mineral species are described, among them 29 which were not known to Werner. The nomenclature of minerals used depends on the classes distinguished. Apart from such polonized generally accepted names such as zircon, vesuviante or leucite, there are some new, later widely used names such as hornstone, pitchstone, etc. In this textbook, salts have chemical names such as calcium carbonate, magnesium sulphate or sodium chloride. Ore minerals are named after the metals they contain, e.g. native silver, arsenious silver, or black silver. Apart from the Polish names of minerals, Drzewiński presents, in the headings, their

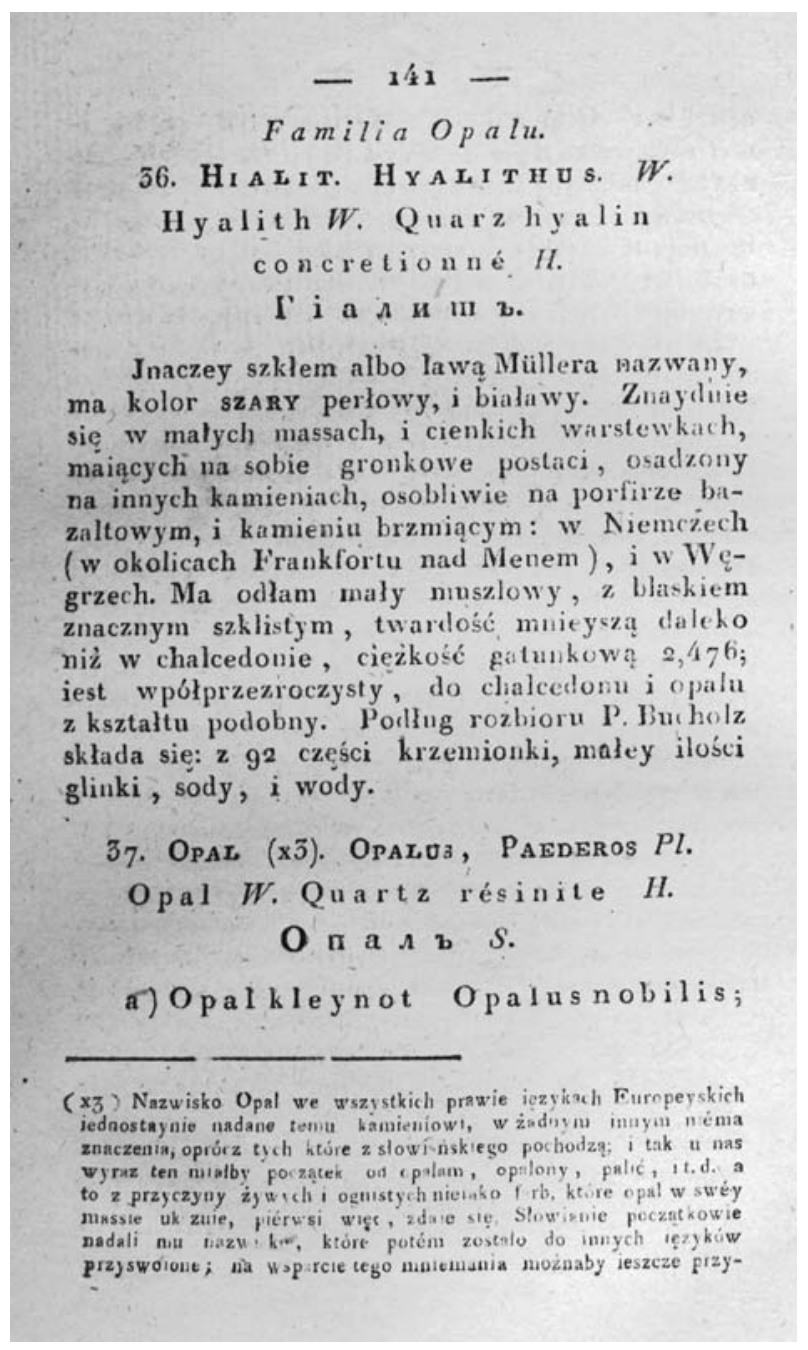

Fig. 4. Example of mineral descriptions in "Poczatki mineralogii podtug Wernera ułożone dla stuchaczów akademickich" (Rudiments of mineralogy according to Werner arranged for listeners of academic lectures) by Felix Drzewiński 
Latin, German, French and Russian synonyms (Fig. 4). Each mineral species is characterized by its external features, crystalline form, occurrence, specific weight and chemical composition, usually after M.H. Klaproth.

The second, shorter part of this textbook is devoted to geognosy, i.e. the description of rocks. They are subdivided, following Werner's classification, into four classes. Among such primary rocks (class I) as granite, gneiss, schists, traps, porphyry, syenite and serpentine, there are also primitive limestone and massive gypsum. Transition rocks (class II) are represented by gray wackes, marbles and some varieties of traps: mandelstones, and pillow lavas. Other varieties of these rocks such as greenschists, basalts containing enclaves of other rocks, and basaltic tuffs are classified together with sandstones, stratiform limestones and gypsum, rock salt and coal as layered rocks (class III). Finally, all sedimentary rocks, being the products of the decomposition

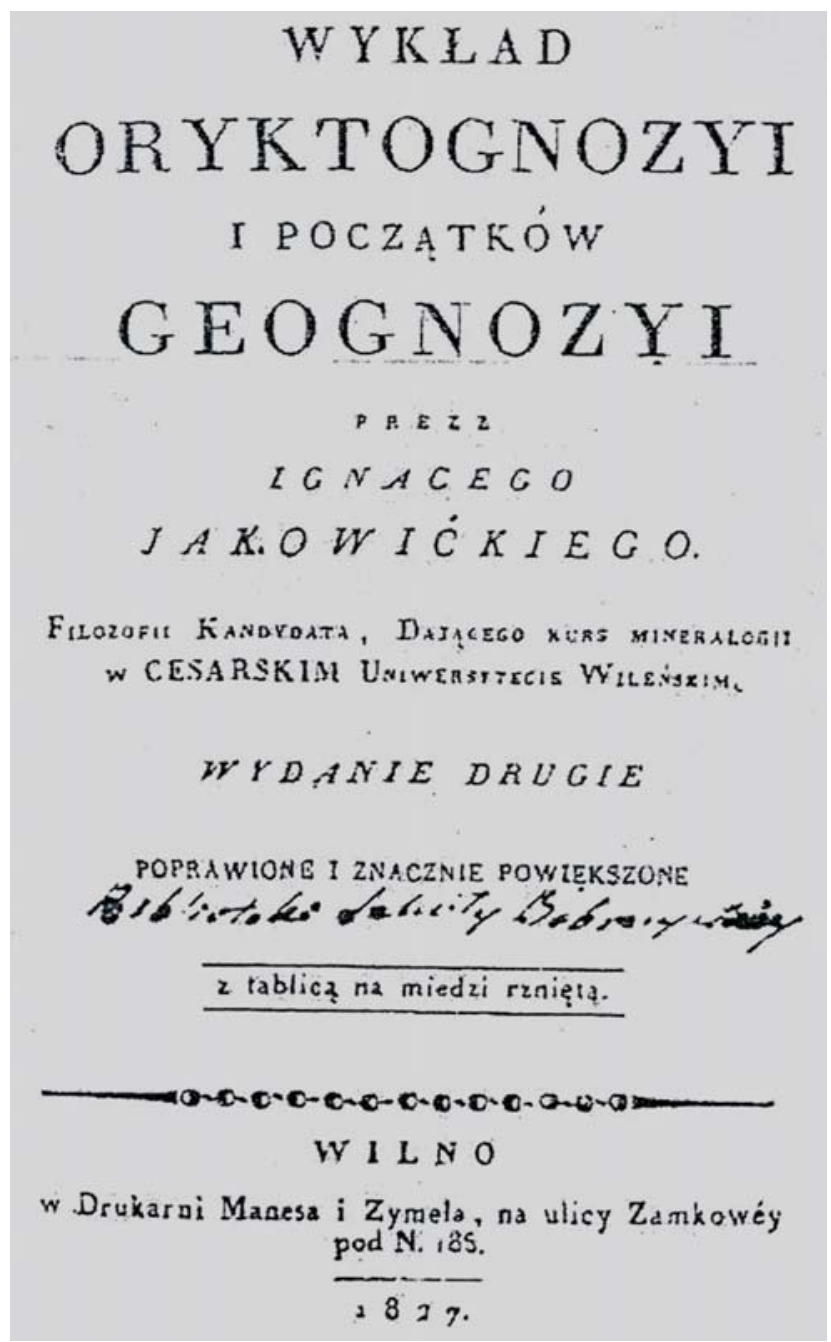

Fig. 5. Title page of "Wykłady oryktognozyi i poczqtków geognozyi” (Lectures on oryctognosy and the rudiments of geognosy) by Ignacy Jakowicki 
of primary rocks, and the transportation and deposition of this material by water, are assigned to the IVth class. A very small group of rocks, classified as volcanics (class V) is composed, following Werner's neptunistic approach, only of volcanic ashes and tuffs. It should be emphasized that the majority of rock names are given not only in Polish but also in German, English and French. Summing up, it may be concluded that an unquestionable credit goes to Drzewiński for his proposition of Polish nomenclature of minerals and rocks, whereby the majority of the polonized names correspond to generally accepted international terms.

The next textbook on mineralogy entitled "Wykłady oryktognozyi i poczatków geognozyi" (Lectures on oryctognosy and the rudiments of geognosy) was published in Vilna in 1825, and reedited in 1827, by Ignacy Jakowicki (1794-1847), another of Werner's students and a lecturer at the Tsar's University (Fig. 5). It should be considered rather as a supplement to the pione-

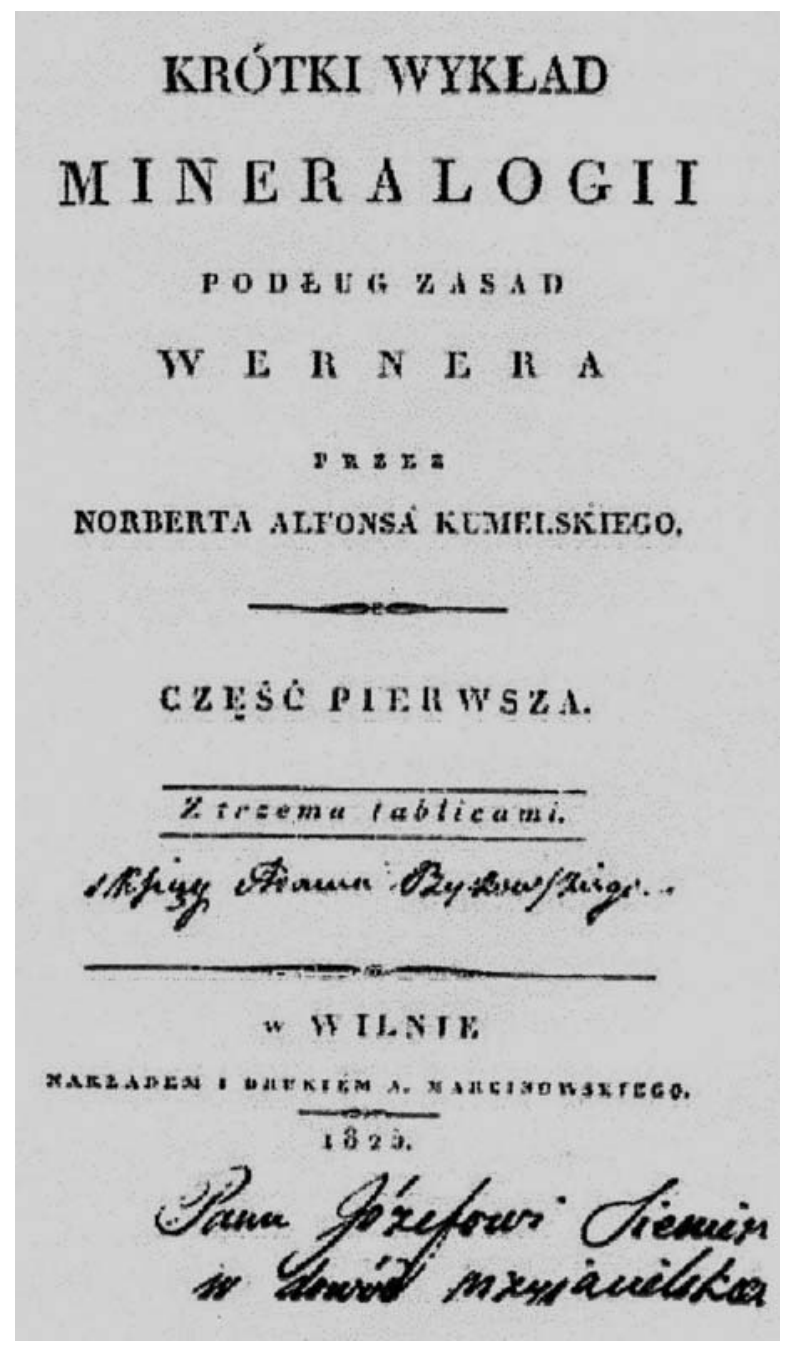

Fig. 6. Title page of "Krótki wykład mineralogii podtug zasad Wernera; Część pierwsza" (Short course of mineralogy according to Werner's principles; Part 1) by Norbert Alfons Kumelski 
ering monograph of Drzewiński. The author introduced some new data, copied from recent monographs of A. Baudant, A. Breithaupt, R. J. Haüy and others; he presented, e.g. Breithaupt's scale of hardness. Much more detailed is the chapter on chemical methods containing a more extensive description of blowpipe analysis and the application of chemical reagents. In the final part of this textbook, Jakowicki described 77 minerals discovered after Werner's death.

In the same year (1825), the first volume of another short textbook on mineralogy entitled "Krótki wyktad mineralogii podtug zasad Wernera" (Short course of mineralogy according to Werner's principles) was published in Vilna (Fig. 6 and 7). Its author, Norbert Alfons Kumelski (1802-1853), though having been also one of Werner's students, paid much more attention to the crystallographic forms of minerals, appreciating the achievements of the French mineralogical school. This is evidenced in a special chapter containing 34 drawings of different crystal habits

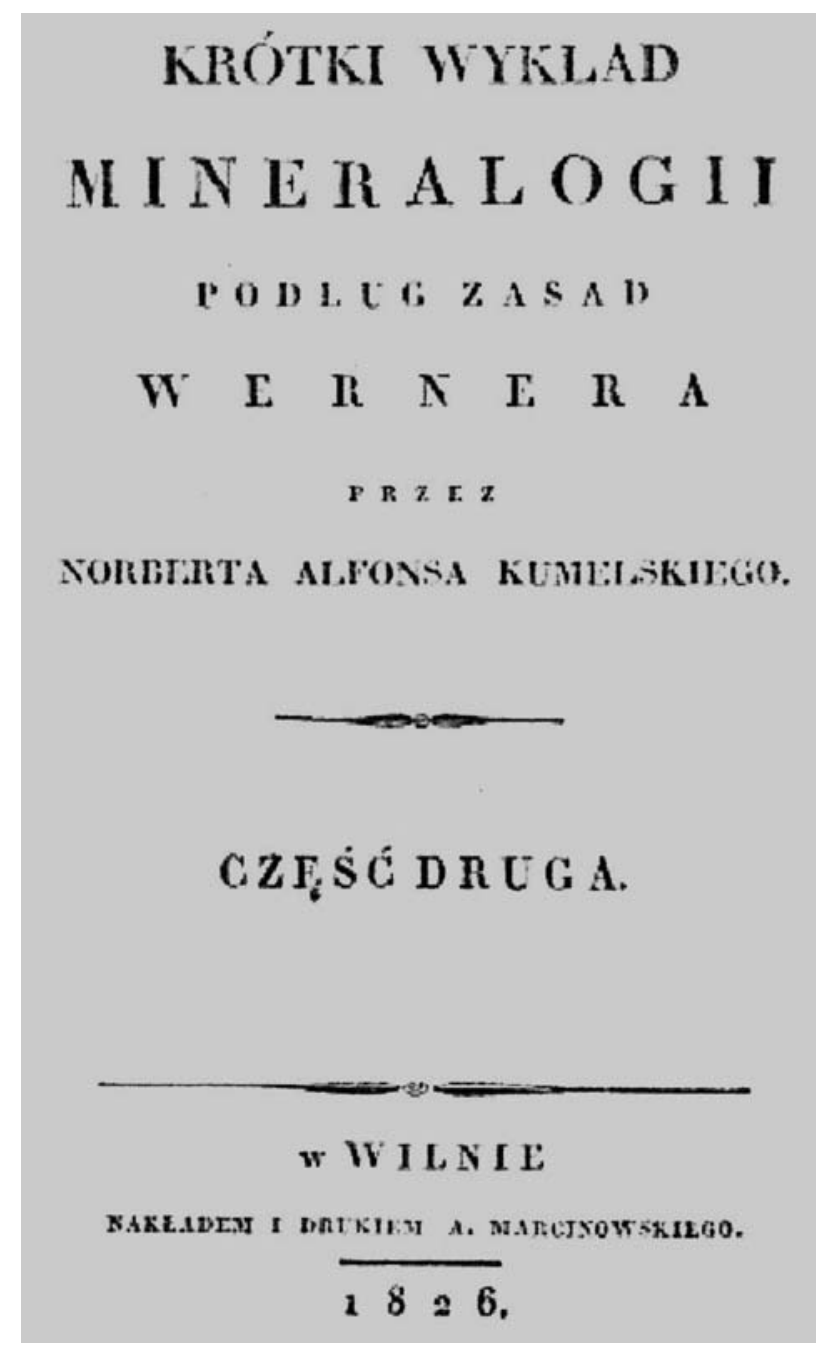

Fig. 7. Title page of "Krótki wykład mineralogii podtug zasad Wernera; Czesśc druga" (Short course of mineralogy according to Werner's principles; Part 2) by Norbert Alfons Kumelski (part 2) 
and their mutual relations. Kumelski was also the first Polish mineralogist to describe wet and dry methods for the chemical analysis of minerals and rocks. It merits noting that the main definitions are presented in the form of questions and answers. in the introductory part of this textbook (Fig. 8).

Kumelski was also the author of the first Polish book on palaeontology entitled "Rys systematyczny nauki o skamieniałościach, czyli petrofaktologii" (Systematic outline of petrofactology or the science of fossils), published in 1826. Another of Kumelski's books is entitled "Zasady geognozyi wedle nauki Wernera" (Principles of geognosy after Werner). This book presents a basic outline of the problems of petrography. Moreover, Kumelski has translated C.P. Brard's manual "Minéralogie appliquée aux Arts" entitled "Mineralogia popularna albo Przestrogi dla Rolników i Rzemieślników" (Popular mineralogy for artisans and farmers),

\section{WIADOAIOŚCI WSTLPQNE.}

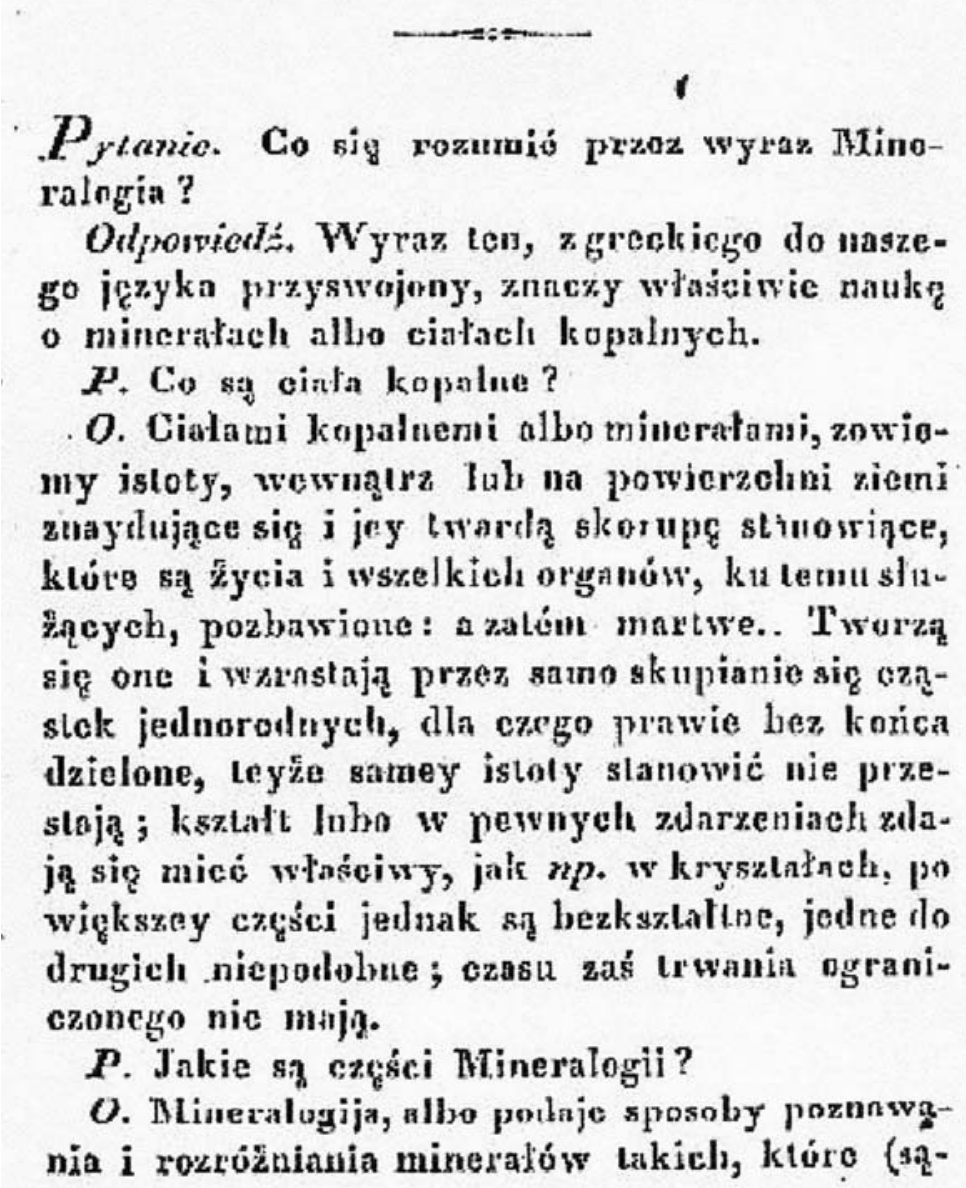

Fig. 8. Introduction to "Krótki wykład mineralogii podtug zasad Wernera"

(Short course of mineralogy according to Werner's principles) by Norbert Alfons Kumelski 


\section{$-4-$}

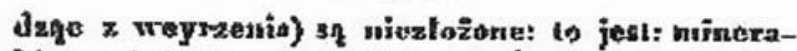
Tów pojedyricz.ych, uadając im raxem slate nazwiska i szykujige w pewwy perxigutelk poiltug raz

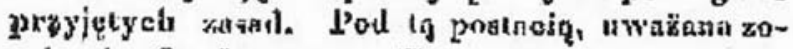

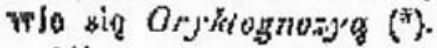

Alho, zwruca urnge na minormy ridocrio blokoue i w widkich massach; wa ul w*ojeanne

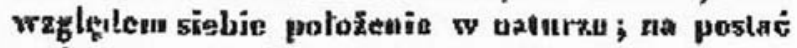
tyel, mass; na ich wrylekluz datwotode; ma rozjanity sposób potralanis : słomeu ux to isszyslko,

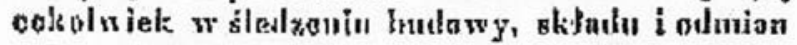
ontey dsali ziemalkloy, npatrywac natua; "tonc8ny zavie sic Gughnozsa (*). . Nosi les nazwi-

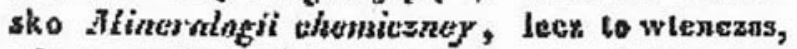
bily tuzy ślealzic w viatreh kopalayoh jels pierưiastków; to jest: 1'azmaitych istol naypronszyeh

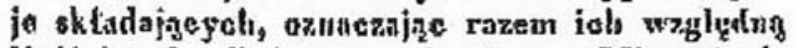
引lość i 1.d. Brúcs togra, jest jeszere Minurulogia

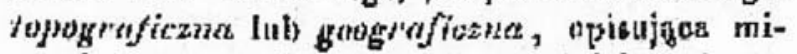
nern'y, Jófuya kxniman gieui witobive; i slosowasua kitórey jurzodujolem jest, wylknņó le tylko minerały, jakie aig kurzystuie w rgkodziel-

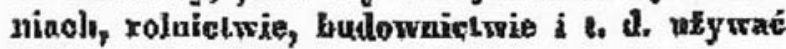
noghe.

(") Oryktoguazys, wyraz Eraeki, alokiony a egixzos [cjole kepalnt) I grovic (posnanic), ensosy dos\}ótruie paznasanie Arnitem.

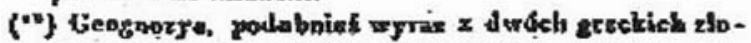

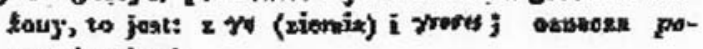
snamia siemi,

Fig. 8 cont. Introduction to "Krótki wyklad mineralogii podtug zasad Wernera"

(Short course of mineralogy according to Werner's principles) by Norbert Alfons Kumelski

published in 1827 , and devoted to the practical study and application of useful minerals by these segments of the population.

Summing up, it is concluded that during the first three decades of $19^{\text {th }}$ century, Alma Mater Vilnensis was one of the leading centres for the mineralogical sciences in Central Europe. This is evidenced by the six original textbooks mentioned above, all edited in Vilna, and representing the highest scientific standards of the period. 


\section{References}

Bolewski A. (1965). Zarys historii mineralogii (Outline of the history of mineralogy). In: W. Żabiński \& J. Kubisz (Eds.), Mineralogia ogólna (General mineralogy, pp. 417-435). Warszawa, Poland: Wydawnictwa Geologiczne (in Polish).

Koziorowski K. (1925). Materjały do dziejów mineralogii w Polsce (Materials to the history of mineralogy in Poland). In: Poradnik dla samouków (vol. V), Mineralogia i petrografia, (pp. 627-701). Warszawa, Poland: Wydawnictwo A. Heflicha i St. Michalskiego (in Polish).

Morozewicz J. (1900). Przegląd historyczny podręczników mineralogii w Polsce (Historical review of mineralogy textbooks in Poland). In: G. Tschermak Podręcznik mineralogii (Mineralogy textbook, pp. 1-39). Warszawa, Poland: Biblioteka Przyrodnicza „Wszechświata” (in Polish). 